\title{
Can COVID-19 cause myalgia with a completely different mechanism? A hypothesis
}

\author{
Adem Kucuk $^{1}$ (D) $\cdot$ Medine Cumhur Cure $^{2}$ (D) Erkan Cure $^{3}$ (D)
}

Received: 28 April 2020 / Revised: 28 April 2020 / Accepted: 15 May 2020/Published online: 26 May 2020

(C) International League of Associations for Rheumatology (ILAR) 2020

\section{Dear Sir,}

Myalgia is a common symptom in patients with viral infections such as novel coronavirus disease 2019 (COVID-19) and influenza. Myalgia reflects generalized inflammation and cytokine response and can be the onset symptom of $36 \%$ of patients with COVID-19 [1]. Back pain in COVID19 may usually indicate pneumonia. Why is the common myalgia caused by COVID-19 longer and more severe than myalgia of other viral infections? Myalgia and fatigue in patients with COVID-19 may be longer in duration than other viral infections and may be unresponsive to conventional painkillers. According to our observation, when viral load is reduced with virus treatment, muscle pain may decrease. In addition to the classic mechanisms of myalgia known in viral infections, COVID-19 can cause musculoskeletal pain with completely different mechanisms.

COVID-19 enters the cell by penetrating ACE2 at low cytosolic $\mathrm{pH}$ and causes infection in the pulmonary system $[2,3]$. The presence of ACE2 has also been demonstrated in the brain, kidney, vascular smooth muscle, and skeletal muscles $[4,5]$. A recent article reported that lactate levels increased due to surplus cell damage during COVID-19 infection [6]. In hyperlactatemia, the oxygen-carrying capacity of

Erkan Cure

erkancure@yahoo.com

Adem Kucuk

drademk@gmail.com

Medine Cumhur Cure

medinecure@yahoo.com

1 Department of Rheumatology, Necmettin Erbakan University, Konya, Turkey

2 Department of Biochemistry, Private Practice, Istanbul, Turkey

3 Department of Internal Medicine, Ota \& Jinemed Hospital, Muradiye Mahallesi Nuzhetiye Cad, Deryadil Sokagi No:1, 34357 Istanbul, Turkey erythrocytes to the tissues is impaired and the tissues remain hypoxic. The virus can spread through the bloodstream or vascular endothelium and cause infection in all tissues containing ACE2 such as the heart and brain. Therefore, the musculoskeletal system can also undergo infection. Increasing creatinine kinase levels during COVID-19 infection proves muscle involvement.

When muscle tissue cannot provide the necessary energy in aerobic ways during exercise, lactate begins to accumulate in the muscles. Monocarboxylate transporter (MCT) (synonym, lactate $/ \mathrm{H}^{+}$ion symporter) is activated to prevent lactate accumulation [7]. MCT pumps lactate and $\mathrm{H}^{+}$ion simultaneously from the extracellular space to the intracellular space and from the intracellular space to the mitochondria. In anaerobic conditions, lactate dehydrogenase (LDH) increases lactate formation from pyruvate $[7,8]$. Under normal conditions, MCTs increase between 32 and $76 \%$ during exercise [7, 8]. During intensive exercise, MCT capacities may increase up to 3-4 times as maximum [7]. Due to exceeding the capacity of MCTs and other regulatory pumps, lactate and $\mathrm{H}^{+}$ion accumulation occur in the cytosol, and the cytosol $\mathrm{pH}$ decreases [8]. ATP synthesis is reduced due to anaerobic glycolysis. Decreased ATP synthesis and low intracellular $\mathrm{pH}$ cause pain and fatigue $[7,9]$. In hyperlactatemia, the oxygen-carrying capacity of erythrocytes and the transport of oxygen to the tissues are highly reduced. As if exercising intensely, the musculoskeletal system may remain deoxygenated and muscles may take place ischemic during COVID-19 infection. Therefore, pain may occur in the muscle tissues remaining ischemic with a mechanism similar to sickle cell disease. Also, during the hypoxic ischemia, the increase of growth factors, cytokines levels, ischemic conditions, and microvascular changes can trigger pain by overexpression in the dorsal root ganglion [10].

In conclusion, LDH increases when the virus damages muscles and other tissues. Due to both increased LDH and anaerobic glycolysis, lactate level may increase excessively. Cytosolic pH may decrease more. Muscle pain may increase 
further due to increased lactate levels, low $\mathrm{pH}$, and low oxygen levels. It is necessary to eliminate the cause of hypoxia for treatment in this pain type. Painkillers may not be effective. When the virus load decreases, the oxygenation of erythrocytes increases, and muscle lactate level decreases. Pain can disappear with virus treatment.

\section{Compliance with ethical standards}

Disclosures None.

\section{References}

1. Lippi G, Wong J, Henry BM (2020) Myalgia may not be associated with severity of coronavirus disease 2019 (COVID-19). World J Emerg Med 11:193-194

2. Cure E, Cumhur Cure M (2020) Comment on "Organ-protective Effect of Angiotensin-converting Enzyme 2 and its Effect on the Prognosis of COVID-19”. J Med Virol. https://doi.org/10.1002/ jmv. 25848

3. Cure E, Cumhur Cure M (2020) Angiotensin-converting enzyme inhibitors and angiotensin receptor blockers may be harmful in patients with diabetes during COVID-19 pandemic. Diabetes Metab Syndr 14:349-350
4. Cure E, Cumhur Cure M (2020) Comment on 'Should COVID-19 Concern Nephrologists? Why and to What Extent? The Emerging Impasse of Angiotensin Blockade'. Nephron 144:251-252. https:// doi.org/10.1159/000507786

5. Echeverría-Rodríguez O, Gallardo-Ortíz IA, Del Valle-Mondragón L, Villalobos-Molina R (2020) Angiotensin-(1-7) participates in enhanced skeletal muscle insulin sensitivity after a bout of exercise. J Endocr Soc 4. https://doi.org/10.1210/jendso/bvaa007

6. Cure E, Cumhur Cure M (2020) Can dapagliflozin have a protective effect against COVID-19 infection? A hypothesis. Diabetes Metab Syndr 14:405-406

7. Juel C, Halestrap AP (1999) Lactate transport in skeletal muscle role and regulation of the monocarboxylate transporter. J Physiol 517(Pt 3):633-642

8. Messonnier L, Kristensen M, Juel C, Denis C (2007) Importance of $\mathrm{pH}$ regulation and lactate/ $\mathrm{H}+$ transport capacity for work production during supramaximal exercise in humans. J Appl Physiol 102: 1936-1944

9. Liang CZ, Li H, Tao YQ, Zhou XP, Yang ZR, Li FC, Chen QX (2012) The relationship between low $\mathrm{pH}$ in intervertebral discs and low back pain: a systematic review. Arch Med Sci 8:952-956

10. Queme LF, Ross JL, Jankowski MP (2017) Peripheral mechanisms of ischemic myalgia. Front Cell Neurosci 11:419

Publisher's note Springer Nature remains neutral with regard to jurisdictional claims in published maps and institutional affiliations. 